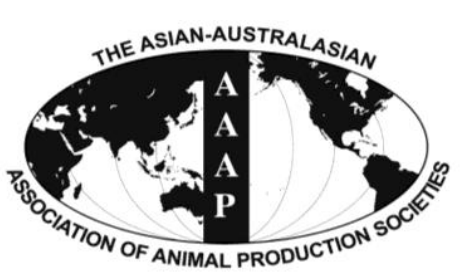

Open Access

Asian Australas. J. Anim. Sci.

Vol. 27 , No. $7:$ 1050-1056 July 2014

http://dx.doi.org/10.5713/ajas.2013.13534

www.ajas.info

pISSN 1011-2367 elSSN 1976-5517

\title{
Factors Affecting Process Temperature and Biogas Production in Small-scale Rural Biogas Digesters in Winter in Northern Vietnam
}

\author{
C. H. Pham*, C. C. Vu, S. G. Sommer ${ }^{1}$, and S. Bruun ${ }^{2}$ \\ Ministry of Agriculture and Rural Development, National Institute of Animal Sciences, \\ Hanoi 10000, Vietnam
}

\begin{abstract}
This study investigated the main factors influencing digester temperature and methods to reduce heat losses during the cold season in the subtropics. Four composite digesters (two insulated and two uninsulated) were buried underground to measure their internal temperature $\left({ }^{\circ} \mathrm{C}\right)$ at a depth of $140 \mathrm{~cm}$ and $180 \mathrm{~cm}$, biogas production and methane $\left(\mathrm{CH}_{4}\right)$ concentration in biogas from August to February. In parallel the temperature of the air (100 cm above ground), in the slurry mixing tank and in the soil $(10,100,140$, and 180 $\mathrm{cm}$ depth) was measured by thermocouple. The influent amount was measured daily and the influent chemical composition was measured monthly during the whole experimental period. Seasonal variations in air temperature significantly affected the temperature in the soil, mixing tank and digester. Consequently, biogas production, which is temperature dependent, was influenced by the season. The main factors determining the internal temperature in the digesters were insulation with Styrofoam, air temperature and temperature of slurry in the mixing tank. Biogas production is low due to the cold climate conditions in winter in Northern Vietnam, but the study proved that storing slurry in the mixing tank until its temperature peak at around 14:00 $\mathrm{h}$ will increase the temperature in the digester and thus increase potential biogas production. Algorithms are provided linking digester temperature to the temperature of slurry in the mixing tank. (Key Words: Digester Temperature, Air and Soil Temperature, Insulation, Season, Simple Biogas Digester)
\end{abstract}

\section{INTRODUCTION}

Efficient utilization of animal waste provides an opportunity to produce renewable energy and also reduce greenhouse gas (GHG) emissions. Implementing efficient technologies is especially challenging in remote areas of developing countries ( $\mathrm{Cu}$ et al., 2012). Millions of simple biogas digesters have been constructed to produce biogas, mainly for cooking and lighting in China, India, Vietnam, Bangladesh, Tibet and Pakistan (Bruun et al., 2014). Most biogas digesters in these countries are made out of bricks,

\footnotetext{
* Corresponding Author: C. H. Pham. Tel: +84-9-6624-0186, Fax: +84-4-3-838-9775, E-mail: phu@kbm.sdu.dk

${ }^{1}$ Institute of Chemical Engineering, Bio- and Environmental Engineering, Faculty of Engineering, University of Southern Denmark, DK5230 Odense, Denmark.

2 Department of Plant and Environment, Faculty of Science, University of Copenhagen, DK1871 Frederiksberg, Denmark.

Submitted Aug. 28, 2013; Revised Dec. 24, 2013; Accepted Jan. 27, 2014
}

concrete or plastic composite, and are unheated and unstirred (simple biogas digesters). $\mathrm{Cu}$ et al. (2012) found that $77 \%$ of biogas digesters in Northern Vietnam and $100 \%$ of those in Central Vietnam were dome digesters made of bricks. The remaining biogas digesters in Northern Vietnam are cylinder digesters made of bricks, plastic composite or other materials. These simple biogas digesters are buried underground to achieve a more stable internal temperature. This is especially important in subtropical climates with relatively cold winters (Kossmann et al., 1997). Temperature is the most important factor affecting biogas production. The effect of temperature on biogas production has been included in many kinetic models of biogas production (e.g. Chen and Hashimoto, 1978; Gavala et al., 2003; Ma et al., 2013).

Although simple biogas digesters are buried in the ground, low temperatures may restrict biogas production in the winter in subtropical areas, especially in mountainous areas (Cu et al., 2012). This makes biogas a less reliable 
energy source and can often be a reason for farmers choosing alternative sources (Bruun et al., 2014). The temperature in the digesters in winter is likely to be affected by a range of different factors, but primarily by air temperature, degree of heat exchange between the digester and the air, soil temperature, temperature of inflowing slurry (which is again influenced by air temperature), temperature of the washing water etc. In order to find simple ways to maintain higher temperatures during winter, it is important to understand the main driving factors influencing digester temperature. The aim of the present paper was therefore to investigate the main factors influencing the temperature of digesters in Northern Vietnam and to identify ways of keeping the temperature high during the winter. More specifically, the effect of insulating the digesters on the temperature inside the digester and the consequent effects on biogas production were investigated.

\section{MATERIALS AND METHODS}

Four biogas composite digesters $\left(7 \mathrm{~m}^{3}\right.$ total volume per digester, $200 \mathrm{~cm}$ diameter) were used for the experiments. They were buried underground (at a depth of about $260 \mathrm{~cm}$ ) at an altitude of $12 \mathrm{~m}$ above sea level (a.s.l.) at the Pig Research Centre, National Institute of Animal Science (NIAS), Thuyphuong, Tuliem, Hanoi, Vietnam. Before the experiment, the digesters were tested for leaks by pumping water into them and monitoring the water level for one week. Two digesters were insulated with a $24 \mathrm{~cm}$ layer of Styrofoam on top of the digester, while two digesters were uninsulated. Initial feedstock of $5,000 \mathrm{~kg}$ pig slurry $(2.50 \%$ dry matter $[\mathrm{DM}])$, accounting for about $70 \%$ of the digester volume, was fed into each digester on day 1 of the experimental period (10 July 2012), and then left for around 15 days to allow the microbial community to develop (Nguyen et al., 2010). Thereafter, approximately $140 \mathrm{~kg}$ of pig slurry $(0.60 \%$ to $1.16 \% \mathrm{DM})$ was added to each digester every day, resulting in a retention time of 40 days.
The pig slurry used as feedstock in the digesters was collected daily from the NIAS pig farm where the pigs are kept in an open pig house. In addition, a sample of pig slurry was collected for DM determination. A mixing tank was used to store the pig slurry before it was fed into the digesters. The pig slurry samples collected daily were combined into monthly samples and used to determine $\mathrm{pH}$, volatile solids (VS), volatile fatty acids (VFA), lignin, crude fiber (CF), crude lipid, total nitrogen, and total ammonia nitrogen (Table 1). Dry matter, total nitrogen, total ammonia nitrogen, CF, lignin, crude lipid and VS were analyzed using TCVN 4326-2001, a Kjeldahl method (Tecator Kjeltec 1030, [Foss, Höganäs, Sweden]), a Fluostar microplate reader (BMG Labtechnologies $\mathrm{GmbH}$, Offenburg, Germany), TCVN-4329-93, AOAC 973.18.01, TCVN 4331-2001, and TCVN-4327-93 respectively. Volatile fatty acids were determined according to the method of Lahav et al. (2002). Slurry $\mathrm{pH}$ was determined by a $\mathrm{pH}$ meter (HI 8424 HANNA, USA, Hach Company, Loveland, CO, USA).

For each digester, the volume of biogas produced was measured daily from August to November 2012, and twice a week from December 2012 to February 2013. The reason for the lower sampling frequency in the latter period was low biogas production in the cold winter conditions. A Flonidan smart gas meter (G4, GALLUS LNE-11827 2011, Denmark) was used to measure biogas volume by releasing the produced biogas through a pipe connected to the instrument until the pressure in the digester headspace was reduced to the ambient atmospheric pressure. Biogas samples were stored in gas bags, and the concentration of methane $\left(\mathrm{CH}_{4}\right)$ and carbon dioxide $\left(\mathrm{CO}_{2}\right)$ was measured weekly by a Visit 03 device (Messtechnik EHEIM GmbH, Schwaigern, Germany). The Visit 03 device was calibrated by standard gas before the biogas concentration was measured.

Temperature probes (EL-USB-1, Lascar Electronics, Module House White Parish Salisbury SP525J, UK) with a temperature range from -35 to $+80^{\circ} \mathrm{C}$ and $\pm 1^{\circ} \mathrm{C}$ accuracy were set up to measure the temperature in the slurry mixing

Table 1. Mean monthly characteristics of the pig slurry used as feedstock for the digesters in the experiment

\begin{tabular}{|c|c|c|c|c|c|c|c|}
\hline & \multicolumn{5}{|c|}{2012} & \multicolumn{2}{|c|}{2013} \\
\hline & Aug. & Sept. & Oct. & Nov. & Dec. & Jan. & Feb. \\
\hline$\overline{\mathrm{pH}}$ & 7.39 & 7.49 & 7.48 & 7.47 & 7.40 & 7.63 & 7.26 \\
\hline $\mathrm{DM}(\%$ in total mass) & 1.68 & 1.35 & 1.10 & 0.60 & 0.59 & 1.16 & 1.61 \\
\hline $\mathrm{VS}(\mathrm{g} / \mathrm{kg})$ & 11.3 & 9.08 & 7.4 & 4.04 & 3.97 & 7.80 & 10.83 \\
\hline Crude lipid (g/kg) & 0.99 & 0.48 & 0.37 & 0.12 & 0.11 & 0.18 & 0.23 \\
\hline Crude fiber $(\mathrm{g} / \mathrm{kg})$ & 2.84 & 1.54 & 1.48 & 0.40 & 0.40 & 0.37 & 0.93 \\
\hline Lignin $(\mathrm{g} / \mathrm{kg})$ & 2.04 & 1.14 & 0.81 & 0.31 & 0.25 & 0.26 & 0.61 \\
\hline Total nitrogen $(\mathrm{g} / \mathrm{kg})$ & 0.82 & 1.00 & 0.60 & 0.49 & 0.57 & 1.27 & 0.63 \\
\hline Total ammonia nitrogen $(\mathrm{g} / \mathrm{kg})$ & 0.64 & 0.49 & 0.43 & 0.32 & 0.43 & 0.69 & 0.29 \\
\hline VFA (g/kg) & 2.29 & 1.22 & 0.76 & 0.57 & 1.10 & 1.14 & 1.12 \\
\hline
\end{tabular}

DM, dry matter; VS, volatile solids; VFA, volatile fatty acids. 
tank, the ambient air, the digester and the surrounding soil. The temperature measurements were made at depths of 140 and $180 \mathrm{~cm}$ inside the digester and at depths of 10, 100, 140, and $180 \mathrm{~cm}$ in the soil and in the mixing tank. The reason for the choice of measurement depths of 140 and $180 \mathrm{~cm}$ is that the diameter of digester is around $200 \mathrm{~cm}$, therefore $140 \mathrm{~cm}$ and $180 \mathrm{~cm}$ are representative depths at the center and bottom of the digesters. Air temperature was measured every 30 min from 1 August 2012 to 28 February 2013 at $100 \mathrm{~cm}$ above floor level in the shade inside the animal house.

\section{Calculations and statistical analysis}

Daily biogas production from August to October originated from the first feeding and daily influent, therefore biogas production in this period was calculated as one value (Table 3 ).

Biogas production was measured daily so the temperature data for digesters, soil, air and the mixing tank was recalculated to daily values for the same periods as the biogas measurement in order to facilitate a statistical analysis.

The data was evaluated using analysis of variance followed by a Tukey test where appropriate (SAS 9.2 TS Level 2M0, (SAS Institute Inc., Cary, NC, USA). Linear regression analysis was used to evaluate the relationship between the temperature in the internal digester and the temperature in the mixing tank. In all cases, a significance level of $\alpha=0.05$ was used. When necessary, data was transformed to obtain normality and homogeneity of variances (Zar, 1984).

\section{RESULTS AND DISCUSSION}

\section{Temperature in the air, mixing tank, soil and digester}

There were significant differences in the temperature of

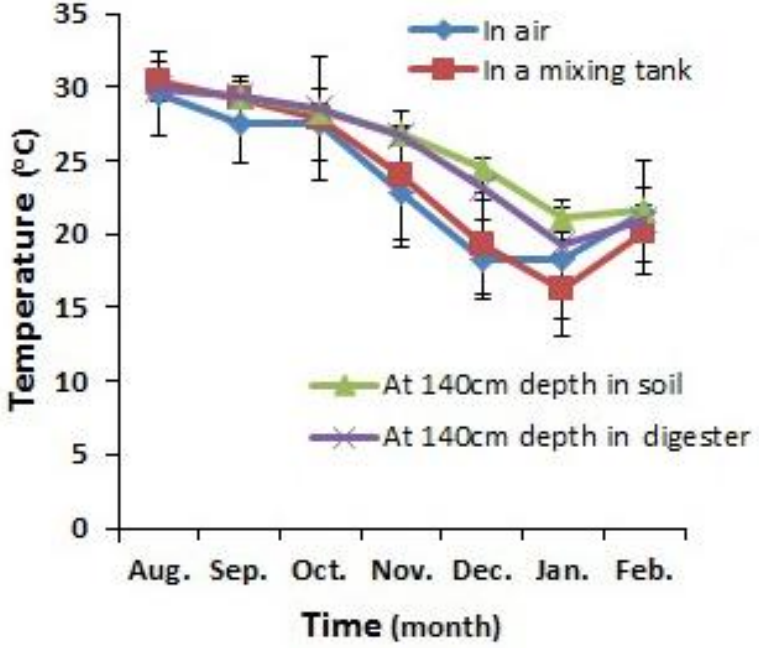

Figure 1. Average monthly temperatures (mean \pm standard deviation) of the air, in a mixing tank used to feed biogas digesters, in the soil at a depth of $140 \mathrm{~cm}$ and at a depth of $140 \mathrm{~cm}$ in an uninsulated digester in winter during the experiment in Northern Vietnam.

the ambient air, in the slurry mixing tank, at a depth of 140 $\mathrm{cm}$ in the soil and at a depth of $140 \mathrm{~cm}$ in the uninsulated digester (Figure 1 and Table 2). The temperature in all four sites decreased slightly, from $30^{\circ} \mathrm{C}$ to $28^{\circ} \mathrm{C}$, from August to October, but dropped dramatically between November and February and was lowest in January. This pattern, where the temperature in the digester is affected by changes in air temperature between the warm and cold seasons, was similar to observations in unheated biogas digesters taken in the hilly regions of India (Kalia and Singh, 1998; Khoiyangbam et al., 2004).

The temperatures in the soil and in the digester were higher than those in the air or in the mixing tank, as shown by Perrigault et al. (2012) who showed that the temperature of an unheated digester followed the trend of the ambient

Table 2. Effect of month, depth in soil, presence of insulation and different environmental conditions on temperature

\begin{tabular}{|c|c|c|c|c|c|c|c|c|c|c|}
\hline \multicolumn{7}{|c|}{ Months } & \multirow{2}{*}{\multicolumn{4}{|c|}{ Different environmental conditions }} \\
\hline Aug. & Sept. & Oct. & Nov. & Dec. & Jan. & Feb. & & & & \\
\hline & & & & & & & \multicolumn{4}{|c|}{ In soil, digester, air, and mixing tank } \\
\hline \multicolumn{7}{|c|}{ Temperature $\left({ }^{\circ} \mathrm{C}\right)$} & In soil & In digester & In air & In mixing tank \\
\hline \multirow[t]{3}{*}{$\begin{array}{c}29.8 \\
(1.49)^{\mathrm{a}}\end{array}$} & $\begin{array}{c}28.9 \\
(1.30)^{b}\end{array}$ & $\begin{array}{c}28.0 \\
(1.83)^{\mathrm{c}}\end{array}$ & $\begin{array}{c}25.0 \\
(2.30)^{\mathrm{d}}\end{array}$ & $\begin{array}{c}21.3 \\
(1.91)^{\mathrm{e}}\end{array}$ & $\begin{array}{c}18.6 \\
(2.18)^{\mathrm{f}}\end{array}$ & $\begin{array}{c}21.0 \\
(1.81)^{\mathrm{e}}\end{array}$ & $\begin{array}{c}25.9 \\
(0.51)^{\mathrm{a}}\end{array}$ & $\begin{array}{c}25.4 \\
(0.56)^{\mathrm{b}}\end{array}$ & $\begin{array}{c}23.5 \\
(3.11)^{\mathrm{c}}\end{array}$ & $\begin{array}{c}23.9 \\
(3.00)^{\mathrm{c}}\end{array}$ \\
\hline & & & & & & & \multicolumn{4}{|c|}{ Depths in soils $(\mathrm{cm})$} \\
\hline & & Temp & ature in $s$ & $\left({ }^{\circ} \mathrm{C}\right)$ & & & 10 & 100 & 140 & 180 \\
\hline \multirow[t]{4}{*}{$\begin{array}{c}29.8 \\
(1.02)^{\mathrm{a}}\end{array}$} & $\begin{array}{c}29.4 \\
(0.85)^{\mathrm{a}}\end{array}$ & $\begin{array}{c}28.4 \\
(0.55)^{\mathrm{b}}\end{array}$ & $\begin{array}{c}26.7 \\
(1.11)^{\mathrm{c}}\end{array}$ & $\begin{array}{c}23.6 \\
(1.03)^{\mathrm{d}}\end{array}$ & $\begin{array}{c}20.4 \\
(1.27)^{\mathrm{f}}\end{array}$ & $\begin{array}{c}21.8 \\
(1.12)^{\mathrm{e}}\end{array}$ & $\begin{array}{c}24.5 \\
(1.91)^{\mathrm{d}} \\
\end{array}$ & $\begin{array}{c}25.4 \\
(0.76)^{\mathrm{c}} \\
\end{array}$ & $\begin{array}{c}25.9 \\
(0.51)^{\mathrm{b}} \\
\end{array}$ & $\begin{array}{c}27.12 \\
(0.71)^{\mathrm{a}} \\
\end{array}$ \\
\hline & & & & & & & \multicolumn{4}{|c|}{ Insulation (depth, cm) } \\
\hline & & & & & & & \multicolumn{2}{|c|}{ With insulation } & \multicolumn{2}{|c|}{ No insulation } \\
\hline & & Temper & Ire in dig & $\operatorname{ers}\left({ }^{\circ} \mathrm{C}\right)$ & & & 140 & 180 & 140 & 180 \\
\hline $\begin{array}{c}29.2 \\
(0.41)^{\mathrm{a}}\end{array}$ & $\begin{array}{c}29.3 \\
(0.45)^{\mathrm{a}}\end{array}$ & $\begin{array}{c}28.4 \\
(0.38)^{b}\end{array}$ & $\begin{array}{c}26.7 \\
(0.62)^{\mathrm{c}}\end{array}$ & $\begin{array}{c}23.6 \\
(0.83)^{\mathrm{d}}\end{array}$ & $\begin{array}{c}20.3 \\
(0.66)^{\mathrm{f}}\end{array}$ & $\begin{array}{c}21.8 \\
(0.90)^{\mathrm{e}}\end{array}$ & $\begin{array}{c}26.0 \\
(0.54)^{\mathrm{a}}\end{array}$ & $\begin{array}{c}25.9 \\
(0.74)^{\mathrm{a}}\end{array}$ & $\begin{array}{c}25.4 \\
(0.56)^{b}\end{array}$ & $\begin{array}{c}25.2 \\
(0.60)^{\mathrm{c}}\end{array}$ \\
\hline
\end{tabular}


temperature. The fact of the soil having a higher temperature than the mixing tank is most probably due to solar heating since soil temperature is higher than air temperature during winter (Huixian et al., 2009). Subsequently in this study, the temperature was higher in the soil than in the digesters in December and January due to the low temperature of the influent slurry and heat losses through the surface of the digester (Khoiyangbam et al., 2004).

\section{Temperature at different depths in the soil}

The temperature in the soil depended on the measuring depth and the month (Figure 2 and Table 2). It remained stable at above $29^{\circ} \mathrm{C}$ from August to September, but declined significantly from October to February, and was lowest in January $(\mathrm{p}<0.0001)$. In January, the temperature increased with increasing depth in soil, and reached its lowest value at a depth of $10 \mathrm{~cm}$ and its highest at a depth of $180 \mathrm{~cm}(\mathrm{p}<0.0001)$. This confirms that in the tropics too, soil temperature at depth is mainly dependent on soil temperature at the surface, the amplitude of the surface soil temperature and the damping depth (Hillel, 1982), and that soil temperatures are more stable at a greater depth than at a shallow depth (Katterer and Andren, 2009). This result is also in agreement with the study of Park et al. (2010) who showed that slurry temperature increased with increasing depth inside the storage tank.

\section{Temperature at depth in digesters with and without insulation}

From August to February, the temperature in the digesters followed a similar trend to that described above in the soil, i.e. digester temperature did not change from August to September, but decreased significantly from October to February and was lowest in January (Figure 3

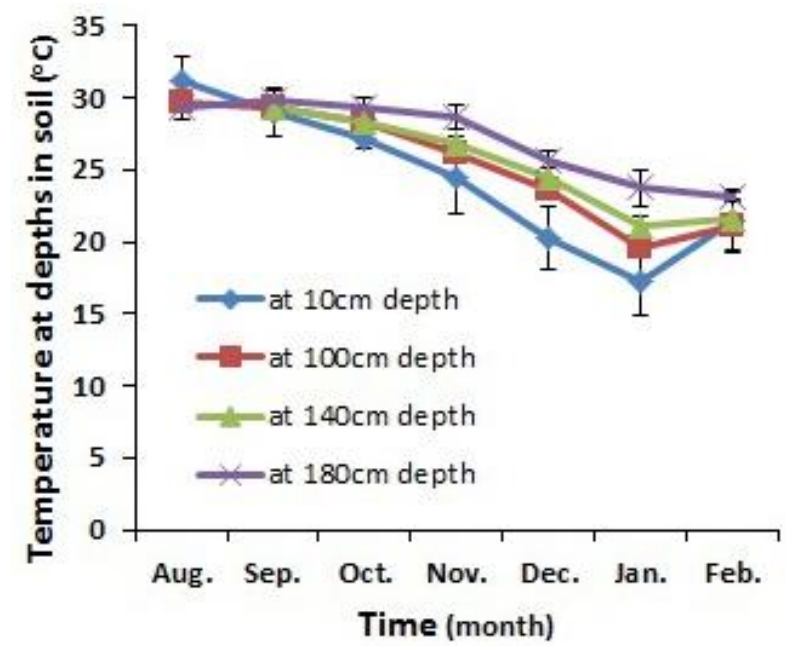

Figure 2. Average monthly temperatures (mean \pm standard deviation) at depths of $10,100,140$, and $180 \mathrm{~cm}$ in the soil during the experiment in Northern Vietnam.

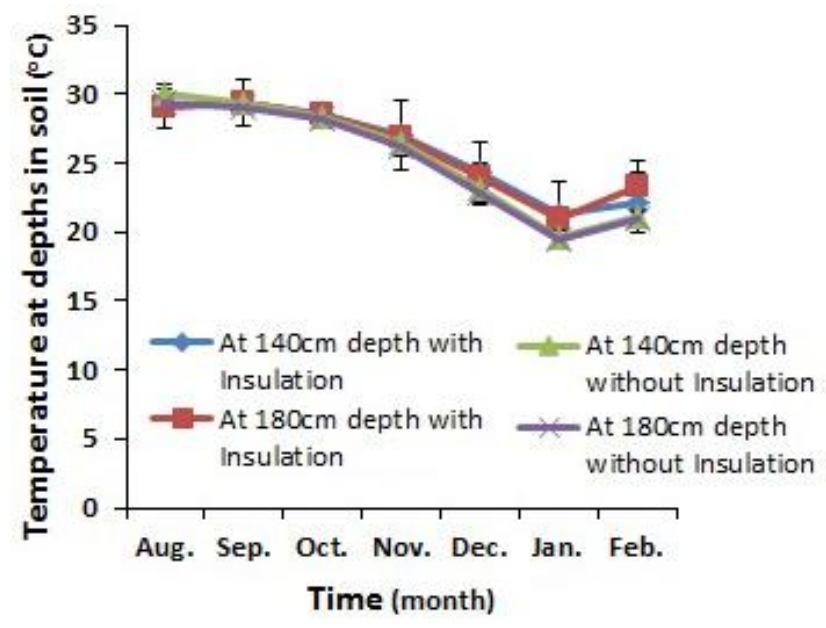

Figure 3. Average monthly temperatures (mean \pm standard deviation) at depths of 140 and $180 \mathrm{~cm}$ in digesters with and without insulation in Northern Vietnam, August 2012-February 2013.

and Table 2). This confirms that simple biogas digesters without heating and stirring are influenced significantly by season, especially in cold winter climates, as shown in studies from the hilly regions of India that have cold winter seasons (Kalia and Kanwar, 1998).

Temperature measurements at depths of 140 and $180 \mathrm{~cm}$ in the insulated and uninsulated digesters showed that digester temperature was significantly related to the month and that the presence of insulation significantly increased the temperature of the biomass in the digester $(p<0.0001)$, confirming that heat loss can be avoided by insulating the digester cover (Wu and Bibeau, 2006; Garfi et al., 2011; Perrigault et al., 2012). In addition, the calculation of $\mathrm{Wu}$ and Bibeau (2006) shows that heat is also lost through the digester walls down to depths of $150 \mathrm{~cm}$. Therefore, insulating the surface and digging the digester deeper into the soil could contribute to a higher digester temperature during the cold season. The results of the present study were more moderate, i.e. insulation increased digestate temperature by $1.5^{\circ} \mathrm{C}$ compared to the results reported by Garfi et al. (2011) that showed an increase of $8.4^{\circ} \mathrm{C}$ and Perrigault et al. (2012) who estimated an increase of $2.1^{\circ} \mathrm{C}$. The difference may be due to the fact that the higher feeding rates in this study contributed to cooling of the digesters. The similar temperatures in the digester at 140 and $180 \mathrm{~cm}$ indicate that the biomass in the digester is stirred by natural convection.

\section{Diurnal variation in mixing tank temperature}

The total volume of the mixing tank constructed to store pig manure before addition to the digester was 1,024 liters (L: $160 \mathrm{~cm}, \mathrm{~W}: 80 \mathrm{~cm}$ and $\mathrm{H}: 80 \mathrm{~cm}$ ). The average temperature in the mixing tank was highest in August (about $30^{\circ} \mathrm{C}$ ), lower in November (about $21^{\circ} \mathrm{C}$ ) and lowest 

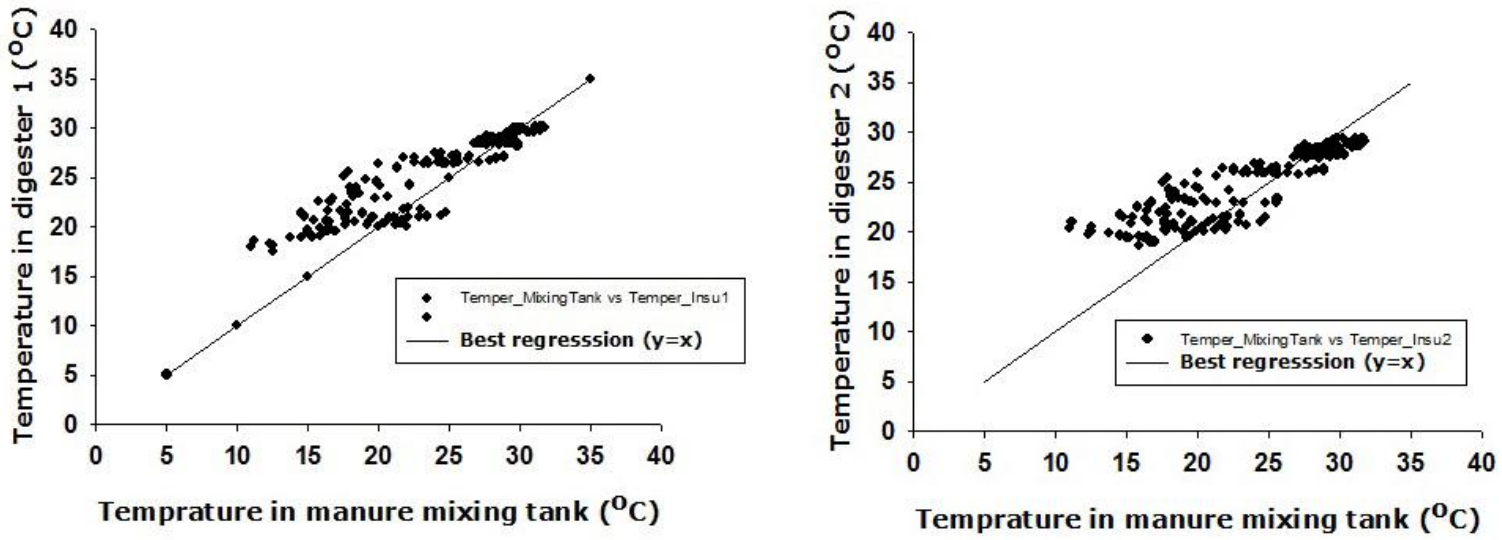

Figure 4. Relationship between the temperature in the mixing tank and inside the uninsulated digesters 1 (left) and 2 (right), August 2012 to February 2013.

in January (around $15^{\circ} \mathrm{C}$ ). In August, the temperature remained fairly constant at around $30^{\circ} \mathrm{C}$ except for a short peak of over $35^{\circ} \mathrm{C}$ at about $16: 00 \mathrm{~h}$. The diurnal temperature in the other months was much more variable, ranging from 17 to over $30^{\circ} \mathrm{C}$ in November and from 11 to $20^{\circ} \mathrm{C}$ in January, but again with a peak of over $30^{\circ} \mathrm{C}$ at about 12:00 $\mathrm{h}$ in November. The variation clearly reflects ambient air temperature and is also affected by solar heating, with the result that the maximum temperature is found a few hours after noon (Khoiyangbam et al., 2004). This result is in agreement with the study of Park et al. (2010) who indicated that the slurry temperature in the storage tank varies due to the variation in atmospheric temperature, and also showed that slurry temperature in the storage tank increased, reaching a peak at midday. This finding can be used to increase the temperature of the digester by feeding the slurry during the time of the day when the temperature is the highest, which in North Vietnam will be at around 14:00 h.

Relationship between the temperature in the digester and in the mixing tank

Understanding the relationship between the temperature in the slurry mixing tank and in uninsulated small-scale digesters may be essential for predicting biogas production and increasing biogas efficiently, but little is known about this relationship in remote areas in poor countries. A significant linear relationship in daily temperature was found between the mixing tank and the digester (Figure 4), so prediction of the temperature in simple biogas digesters is possible using mixing tank temperatures on farms that have limited access to data.

\section{Biogas and methane production}

The effect of the month and of insulation on biogas and methane production is presented in Table 3. Biogas and methane production in February is not presented because of issues with biogas leaking from the insulated digesters. There was no significant difference in methane or biogas production between digesters with and without insulation. The reason for this may be that the $\sim 1^{\circ} \mathrm{C}$ higher temperature in the insulated digesters (Figure 3 and Table 2) was not enough to create a difference in biogas production. In addition, biogas and methane production did not change greatly between August and November, but dropped dramatically in December and January, a pattern similar to the findings in the hilly regions of India (Kalia and Singh, 1998; Khoiyangbam et al., 2004). The reason for this difference is that the air and digester temperature in AugustOctober (summer) was much higher than in DecemberJanuary and there is a cubic relationship between biogas production and the temperature increasing from $10^{\circ} \mathrm{C}$ to $30^{\circ} \mathrm{C}$ (Sommer et al., 2007; Pham et al., 2013, submitted).

\section{CONCLUSIONS}

Time of the year significantly influenced temperatures in the air, the slurry mixing tank, the soil and the digesters.

Table 3. Effect of month and insulation on methane $\left(\mathrm{CH}_{4}\right)$ and biogas production ( $\mathrm{L} / \mathrm{kg}$ volatile solids [VS]) in small-scale composite biogas digesters in Northern Vietnam

\begin{tabular}{|c|c|c|c|c|c|c|c|c|c|}
\hline & \multicolumn{4}{|c|}{ Month } & \multicolumn{2}{|c|}{ Insulation } & \multicolumn{3}{|c|}{$\mathrm{p}$ values } \\
\hline & Aug. to Oct. & Nov. & Dec. & Jan. & $\begin{array}{c}\text { With } \\
\text { insulation }\end{array}$ & $\begin{array}{c}\text { No } \\
\text { Insulation }\end{array}$ & Month & Insulation & $\begin{array}{c}\text { Month } \\
\times \text { Insulation }\end{array}$ \\
\hline$\overline{\mathrm{CH}_{4}(\mathrm{~L} / \mathrm{kg} \mathrm{VS})}$ & $264.1^{\mathrm{a}}$ & $261.7^{\mathrm{a}}$ & $205.0^{\mathrm{b}}$ & $168.5^{b}$ & $221.42^{\mathrm{a}}$ & $228.21^{\mathrm{a}}$ & $<0.0001$ & 0.471 & 0.945 \\
\hline Biogas (L/kg VS) & $381.9^{\mathrm{a}}$ & $378.4^{\mathrm{a}}$ & $318.6^{\mathrm{b}}$ & $254.2^{\mathrm{c}}$ & $339.17^{\mathrm{a}}$ & $327.34^{\mathrm{a}}$ & $<0.0001$ & 0.400 & 0.606 \\
\hline
\end{tabular}

\footnotetext{
${ }^{a, b, c}$ Means in the same row for each factor with different superscripts are significantly different $(\mathrm{p}<0.05)$.
} 
Digester temperature was also significantly influenced by the presence of insulation and the ambient air temperature. Consequently during the winter biogas production was much lower than during the summer. Insulation with a 24 $\mathrm{cm}$ layer of Styrofoam on the surface may not be enough to show a significant difference in biogas production. It seems unlikely that further insulation on the surface would make a significant difference, therefore other approaches to maintaining the temperature in winter should be pursued. It is seen that slurry stored in mixing tanks before being fed into the digester have a peak temperature at 14:00 $\mathrm{h}$ in North Vietnam. One way of taking advantage of this finding could be to have a management strategy of adding slurry from the mixing tank at 14:00 $\mathrm{h}$ because it has been shown in this study that there is a significant relationship between digester temperature and the temperature of the slurry in the mixing tank.

\section{ACKNOWLEDGMENTS}

This study was funded by the Council for Development Research (RUF), Danish Ministry of Foreign Affairs via the SUSANE research project (Sustainable, sanitary and efficient management of animal manure for plant nutrition).

\section{REFERENCES}

Bhattacharya, S. C. and C. Jana. 2009. Renewable energy in India: Historical developments and prospects. Energy 34:981-991.

Bruun, S., L. S. Jensen, T. K. V. Vu, and S. G. Sommer. 2014. Small-scale household biogas digesters: An option for global warming mitigation or a potential climate bomb? Renew. Sust. Energy Rev. 33:736-741.

Chen, Y. R. and A. G. Hashimoto. 1978. Kinetics of methane fermentation. Biotech. Bioeng. Symp. 8:269-282.

Cu, T. T. T., H. C. Pham, T. H. Le, V. C. Nguyen, X. A. Le, X. T. Nguyen, and S. G. Sommer. 2012. Manure management practices on biogas and non-biogas pig farms in developing countries - using livestock farms in Vietnam as an example. J. Clean. Prod. 27:64-71.

Garfi, M., L. Ferrer-Marti, I. Perez, X. Flotats, and I. Ferrer. 2011. Codigestion of cow and guinea pig manure in low-cost tubular digesters at high altitude. Ecol. Eng. 37:2066-2070.

Gautam, R., S. Baral, and S. Heart. 2009. Biogas as a sustainable energy source in Nepal: Present status and future challenges. Renew. Sustain. Energy Rev. 13:248-252.

Gavala, H., I. Angelidaki, and B. Ahring. 2003. Kinetics and modeling of anaerobic digestion process. In: Biomethanation I (Eds. B. Ahring, I. Angelidaki, E. C. Macario, H. N. Gavala, J. Hofman-Bang, A. J. I. Macario, S. J. W. H. O. Elferink, L. Raskin, A. J. M. Stams, P. Westermann, and D. Zheng). Springer, Berlin Heidelberg, Germany. pp. 81:57-93.

Grau, P., M. Dohanyos, and J. Chudoba. 1975. Kinetics of multicomponent substrate removal by activated sludge. Water. Res. 9:637-642.
Hansen, T. L., S. G. Sommer, S. Gabriel, and H. T. Christensen. 2006. Methane production during storage of anaerobically digested municipal organic waste. J. Environ. Qual. 35:830836.

Hillel, D. 1982. Introduction to Soil Physics. Academic Press, San Diego, CA, USA.

Hill, D. T. 1984. Methane productivity of the major animal waste types. Trans. ASAE. 27:530-534.

Hobson, P. N., S. Bousfield, R. Summers, and P. J. Mills. 1980. Anaerobic digestion of piggery and poultry wastes. In: Anaerobic digestion (Eds. B. E. Stafford, B. I. Wheatley, and D. E. Hughes). Applied Science Publishers, London.

Huixian, S. H. I., P. E. I. Xiaomei, Z. H. U. Hongguang, L. U. O. Zhongyang, W. A. N. G. Tao, R. O. N. G. Ling, and L. I. Yongming. 2009. How to compensate the lost temperature of the digester in cold climate. Proceedings of the international conference on power engineering 09 (ICOPE-09) November 16-20, 2009; Kobe, Japan. pp.185-190.

IPCC. 1997. Guidelines for national greenhouse gas inventories: reference manual. Revised 1996. IPCC Guidelines.

Jiang, X., S. G. Sommer, and K. V. Christensen. 2011. A review of the biogas industry in China. Energy Policy 39:6073-6081.

Kalia, A. K. and S. P. Singh. 1998. Horse dung as a partial substitute for cattle dung for operating family-size biogas plants in a hilly region. Bioresour. Technol. 64:63-66.

Kalia, A. K. and S. S. Kanwar. 1998. Long term evaluation of a fixed dome Janata biogas plant in hilly conditions. Bioresour. Technol. 65:61-63.

Katterer, T. and O. Andren. 2009. Predicting daily soil temperature profiles in arable soils in cold temperature regions from air temperature and leaf area index. Acta Agriculturae Scandinavica Section B Soil Plant Sci. 59:77-86.

Khoiyangbam, R. S., S. Kumar, M. C. Jain, N. Gupta, A. Kumar, and V. Kumar. 2004. Methane emission from fixed dome biogas plants in hilly and plain regions of northern India. Bioresour. Technol. 95:35-39.

Kossmann, W., U. Pönitz, and S. Habermehl. 1997. Biogas digest: Biogas application and product development (Volume II). Information and Advisory Service on Appropriate Technology (ISAT) \& GATE in Deutsche Gesellschaft für Technische Zusammenarbeit (GTZ).

Lahav, O., B. E. Morgan, and R. E. Loewenthal. 2002. Rapid, simple and accurate method for measurement of VFA and carbonate alkalinity in anaerobic reactors. Environ. Sci. Technol. 36:2736-2741.

Ma, J., L. Yu, C. Frear, Q. Zhao, X. Li, and S. Chen. 2013. Kinetics of psychrophilic anaerobic sequencing batch reactor treating flushed dairy manure. Bioresour. Technol. 131:6-12.

Martí-Herrero, J. 2007. Transfer of low-cost plastic biodigester technology at household level in Bolivia. Livest. Res. Rural. Dev. 19(12). http://www.lrrd.org/lrrd19/12/mart19192.htm Accessed August 28, 2013.

Møller, H. B., S. G. Sommer, and B. K. Ahring. 2004. Methane productivity of manure, straw and solid fractions of manure. Biomass Bioenergy 26:485-495.

Monod, J. 1949. The growth of bacterial cultures. Annu. Rev. Microbiol. 3:371-394.

Nguyen, D. L., T. K. Nguyen, and K. Q. Nguyen. 2010. Questions 
and answers about biogas technologies. Vietnam Agric. Publishing House.

Park, K. H. and C. W. Riddle. 2010. Methane emission patterns from stored liquid wwine manure. Asian Australas. J. Anim. Sci. 23:1229-1235.

Perrigault, T., V. Weatherford, J. Martí-Herrero, and D. Poggio. 2012. Towards thermal design optimization of tubular digesters in cold climates: A heat transfer model. Bioresour. Technol. 124:259-268.

Pham, C. H., J. M. Triolo, and S. G. Sommer. 2013. Models for predicting methane production in simple and unheated biogas digesters. Applied Energy (Submitted).

Rehm, H. J., G. Reed, A. Puhler, and P. J. W. Stadler. 2000. Biotechnology, vol. 11A: Environmental processes I, 2nd ed., Wiley, New York, USA.

Singh, J. B., M. R. Myles, and A. Dhussa. 1987. Manual on Deenbandhu Biogas Plant. Tata McGraw-Hill. New Delhi, India.
Sodha, M. S., S. Ram, N. K. Bansal, and P. K. Bansal. 1987. Effect of PVC greenhouse in increasing the biogas production in temperature cold climate conditions. Energy Convers. Manag. 27:83-90.

Sommer, S. G., S. O. Petersen, O. Sorensen, H. D. Poulsen, and H. B. Moller. 2007. Methane and carbon dioxide emissions and nitrogen turn-over during liquid manure storage. Nutr. Cycl. Agroecosyst. 78:27-36.

Wu, B. and E. L. Bibeau. 2006. Development of 3-D anaerobic digester heat transfer model for cold weather applications. Trans. ASABE 49:749-757.

Yu, L., K. Yaoqiu, H. Ningsheng, W. Zhifeng, and X. Lianzhong. 2008. Popularizing house-house scale biogas digesters for rural sustainable energy development and greenhouse gas mitigation. Renew. Energy 33:2027-2035.

Zar. J. H. 1984. Biostatistical Analysis, 2nd edn. Prentice-Hall, Englewood Cliffs, NJ, USA.

Zhang, L. Z. Yang, B. Chen, and G. Chen. 2009. Rural energy in China: pattern and policy. Renew. Energy 34:2813-2823. 